\title{
There is Only One Mindfulness: Why Science and Buddhism Need to Work Together
}

\author{
William Van Gordon • Edo Shonin • Mark D. Griffiths • \\ Nirbhay N. Singh
}

Published online: 20 December 2014

(C) Springer Science+Business Media New York 2014

\section{Introduction}

The paper by Monteiro et al. (2015) is to be commended for providing a comprehensive discussion of the compatibility issues arising from the integration of mindfulness - a 2500year-old Buddhist practice - into research and applied psychological domains. Consistent with the observations of various others (e.g. Dunne 2011; Kang and Whittingham 2010), Monteiro et al. have not only highlighted that there are differences in how Buddhism and contemporary mindfulness interventional approaches interpret and contextualize mindfulness, but there are also differing interpretations of mindfulness within Buddhism. These apparent differences within Buddhism are arguably more noticeable when making comparisons across Buddhist vehicles (i.e. Theravada, Mahayana, Vajrayana), but to a lesser extent intra-vehicular differences can also be said to exist (i.e. differences between Buddhist traditions of the same vehicle). This commentary investigates the validity of some of these different Buddhist constructions of mindfulness and then discusses how a better understanding of their scriptural and conceptual soundness (or lack thereof) may help to reconcile some of the actual and perceived incompatibility between Buddhist practice and contemporary secular mindfulness-based approaches.

This commentary then continues by providing an alternative perspective to some of the key arguments and

W. Van Gordon $(\bowtie) \cdot$ E. Shonin • M. D. Griffiths

Psychology Division, Nottingham Trent University,

Nottinghamshire NG1 4BU, UK

e-mail: William@awaketowisdom.co.uk

N. N. Singh

Medical College of Georgia, Georgia Regents University,

Augusta, GA, USA

observations outlined by Monteiro et al. concerning the relative deficiency of authenticity in secular mindfulness-based approaches compared with mainstream Buddhist practice traditions. This is achieved by critically examining the underlying assumption that if secular mindfulness-based approaches represent a more "superficial" construction of mindfulness, then the "superior" approach embodied by present-day Buddhist teachers and traditions should be easily identifiable. More specifically, a means of understanding mindfulness (and related Buddhist meditative principles) is presented that attempts to communicate the versatility and underlying unity of the Buddha's teachings, and the fact that the scriptural, empirical, and logical grounds for asserting that secular mindfulness-based approaches offer a less authentic practice mode than mainstream Buddhist modalities is not as robust as contemporary general opinion might suggest.

\section{One Path}

Following a comprehensive review and analysis of descriptions provided in both the academic and popular contemporary literature, we can categorize terms typically employed to describe or define a Buddhist and/or authentic construction of mindfulness into five different types of meditation and/or awareness:

1. Concentrative meditation - whether as synonymous with or a central component of mindfulness (e.g. sustained attention [Bishop et al. 2004], absorption [McGarvey 2010], focused attention [Kabat-Zinn et al. 1998; Lutz, Slagter, Dunne, and Davidson 2008])

2. Shamatha meditation (e.g. Mipham 2002; Trungpa 2004)

3. Insight/vipassanā meditation (e.g. Bowen et al. 2006; Chiesa 2010; Kabat-Zinn 1982; Sills and Lown 2008) 
4. Mindfulness meditation - typically contextualized as a distinct form of meditation in and of itself, but sometimes referred to utilizing terms such as present moment awareness or moment-by-moment awareness (e.g. Kabat-Zinn 1982, 1990, 1994; Horowitz 2010; Manocha 2000)

5. Open awareness (e.g. bare attention [Brown et al. 2007; Kabat-Zinn 1982; Nyanaponika 1962], choiceless awareness [Krishnamurti 2009], unconstructed awareness [Kang and Whittingham 2010], nonjudgemental awareness, detached observation [KabatZinn 1982])

Despite these various interpretations and descriptions of mindfulness by scholars, researchers, and Buddhist teachers, we argue that, in actual fact, the Buddha taught only one type of mindfulness. Indeed, there is little (if any) ambiguity in the original teachings expounded by the Buddha in terms of how mindfulness should be interpreted and practised. According to the record of the Pāli Canon Sutta Pitaka, the Buddha's first reference to mindfulness was during his Discourse that Sets the Wheel of Dharma in Motion (Dhammacakkappavattana Sutta, Samyutta Nikāya [SN], 56:11; Bodhi 2000) that is believed to represent the first teaching he gave (to the five ascetics) after attaining enlightenment. In this and subsequent discourses, mindfulness was introduced as the seventh aspect of the Noble Eightfold Path. The Noble Eightfold Path corresponds to the path referred to by the Buddha in the fourth of the Four Noble Truths - the path that leads to the cessation of suffering (Van Gordon, Shonin, Griffiths, and Singh, 2014a).

As noted by Monteiro et al., all Buddhist traditions acknowledge the importance of the Noble Eightfold Path. The reason for this is simple; the Noble Eightfold Path is a fundamental teaching that is repeatedly referred to and featured in the Pāli and Chinese Buddhist Canons (and to a lesser extent the Tibetan Buddhist Canon). There are inevitably some differences in how texts within these respective Buddhist canons refer to and explicate the Noble Eightfold Path (the Ekottara Ägama of the Chinese Canon [Taishō Tripițaka 125] being an example of a notable outlier), but for the most part, the basic meaning and principles of the Noble Eightfold Path remain the same in each of the established Buddhist canonical collections. Consequently, although some researchers, scholars, and Buddhist teachers might claim that there exist versions of the Noble Eightfold Path that capture more accurately the intended meaning of the Buddha, and notwithstanding any loss of accuracy due to the passage of time between the expounding and subsequent recording of the Buddha's teachings, the authenticity of the Buddha's Noble Eightfold Path teachings as recorded in, for example, the Sutta Pitaka of the Pāli Canon, cannot not disputed.

Although the Noble Eightfold Path should be regarded as a single (albeit multifaceted) path (Shonin et al. 2014c), the fact that right mindfulness (Pāli: sammā-sati, Sanskrit: samyaksmrti) was included in addition to and separate from right concentration (Pāli: sammā-samādhi, Sanskrit: samyaksamädhi) implies that the Buddha believed that mindfulness and meditative concentration were two distinct faculties. Indeed, had the Buddha believed or personally experienced that mindfulness and meditative concentration were the same construct, then it is logical to assume that in place of the Noble Eightfold Path, he would have expounded the Noble Sevenfold Path in which right mindfulness and right concentration were condensed into a single path element. Furthermore, perhaps of greatest bearing for the purposes of the present commentary, the placement by the Buddha of right mindfulness immediately prior to right concentration indicates that mindfulness is an important (arguably the most important) moderating agent in the cultivation and maintenance of right concentration.

Meditative concentration is the process of focusing attention on a given meditative object (e.g. the breath, a visualization, the mind, or even the present moment more generally) with the primary intention of introducing focus and tranquillity (a wholesome mental factor known as samatha [Pāli, Sanskrit: shamatha]) into the mind (Shonin et al. 2014). Samatha, in turn, facilitates the deepening and stabilization of samadhi, and the interplay and reciprocal feedback between samadhi and samatha (i.e. concentration and tranquillity) provides the optimum conditions for the subsequent cultivation of meditative insight (Shonin. et al. 2014a). However, for various reasons and to varying degrees, the mind of the unaccomplished meditation practitioner has a tendency to be distracted from its object of placement (Chah 2011; Dalai Lama and Berzin 1997). One of these reasons is the fact that the tranquillity associated with meditative concentration can be so blissful and absorbing - it can trigger a loss of meditative concentration (Tsong-Kha-pa 2004). Accordingly, mindfulness performs the primary function of surveying the concentrating mind so that attentional adjustments can be made as required in order to ensure that meditative concentration remains at its optimum (i.e. neither too constricted nor too loose) (Shonin et al. 2014).

Thus, mindfulness regulates the breadth and intensity of meditative concentration, but mindfulness itself is not-and was never explicated by the Buddha as being-meditative concentration (i.e. samadhi). As already indicated, in addition to the Theravada Sutta Pitaka discourses referred to above, this same interpretation of mindfulness - as a faculty that regulates meditative concentration - appears in the core texts of both the Mahayana and Vajrayana Buddhist vehicles. For example, in the Tibetan Buddhist but principally Mahayana text known as the Great Treatise on the Stages of the Path to Enlightenment (Tibetan: lam rim chen mo), the fourteenth century Tibetan Buddhist saint Tsong-kha-pa explicitly described mindfulness as being the function that prevents 
attention from wandering from the object of meditation. Likewise, in the related but principally Vajrayana text known as the Song of the Four Mindfulnesses (not to be confused with the Four Foundations of Mindfulness), the seventh Dalai Lama directs Buddhist followers to place their mind on four different objects of placement. These objects include (i) admiration and respect (for the Buddha and/or teacher), (ii) compassion, (iii) the divine/subtle body (that the meditation practitioner possesses), and (iv) emptiness. He then instructs monastic and lay practitioners to practice mindfulness by "not letting your mind stray" from these four meditative objects and by "making your attention unforgetful" (Gelek 2009, p. 3-5). Therefore, consistent with the Theravada position, Mahayana and Vajrayana Buddhist perspectives clearly depict mindfulness as a faculty that is separate from, but essential to the maintenance of, meditative concentration.

The exact same argumentation applies to claims - often with Mahayana (including Zen) and Vajrayana Buddhist connotations - that mindfulness can be likened to a state of "natural, uncontrived, spontaneously arisen awareness that is inseparable from every moment of experience" (Kang and Whittingham 2010, p. 169), bare attention (Brown. et al. 2007; Nyanaponika 1962), choiceless awareness (Krishnamurti 2009), unconstructed awareness (Kang and Whittingham 2010), or non-judgemental awareness/detached observation (Kabat-Zinn 1982). Such descriptions of mindfulness do not accurately reflect the aforementioned fundamental teachings of the Buddha in, for example, the Noble Eightfold Path, and they assign levels of meaning and profundity to mindfulness that have no scriptural basis in any of the canonical Buddhist collections (Rosch 2007). This is not to say that profound states of mind are not described or attainable in Buddhist practice, but such states should not be confused with the concentration-regulating faculty of mindfulness. The exact same principle and counter-argument applies to assertions that mindfulness is insight/vipassana meditation, samatha meditation, or a form of meditation in and of itself (i.e. mindfulness meditation). At no point did the Buddha state or imply that the term mindfulness (i.e. sati or smrti) can be used interchangeably with these meditative states or modes.

In terms of referring to mindfulness as insight meditation or vipassan $\bar{a}$ meditation, it might be argued that in the Ānāpānasati Sutta (Majjhima Nikāya [MN] 118; Ñanamoli and Bodhi 2009), the final tetrad of the 16 mindfulness of breathing exercises are specifically concerned with the cultivation of insight. This statement is absolutely true because after having performed the first 12 Annapannasati Sutta exercises that specifically relate to cultivating awareness of bodily and psychological phenomena (i.e. whilst utilizing the breath as a meditative anchor), the Buddha then instructs the meditation practitioner to foster awareness of various insight elements and/or spiritual truths (e.g. impermanence, relinquishment of suffering, nirvana, etc.). However, the instructions provided by the Buddha in the final tetrad of the Annappanasati Sutta are not inconsistent with any of his previous or subsequent mindfulness teachings. In the Anāpānasati Sutta, the subjects of each of the 16 exercises (e.g. breath, body, rapture, mental formations, mind, impermanence, etc.) are introduced as meditative objects, and mindfulness is the regulatory process of ensuring that concentration remains placed on the object in question (Shonin et al. 2014a).

Consistent with the traditional samatha-vipassanā meditation model, and with the delineation of ānāpānasati (i.e. mindfulness of breathing) in the Vissuddhimagga (Nanamoli 1979), by meditatively concentrating on the various objects of the first 12 Anāpānasati Sutta exercises, the necessary conditions are fulfilled for the cultivation of tranquil abiding (i.e. samatha). As noted above, tranquil abiding is one of the prerequisites for the cultivation of vipassana (which translates from the Pāli as clear seeing or superior seeing; Shonin, Van Gordon, and Griffiths 2014a). There is debate amongst Buddhist scholars and teachers as to whether the shift in meditative mode from samatha to vipassana is something that happens naturally or whether it requires purposeful effort on the part of the meditator. However, irrespective of which position is favoured (the latter position best reflecting the view and experience of the present authors), the point is that in the Buddha's original ānāpānasati teachings, mindfulness serves to ensure that concentration remains focused on whichever samatha and/or vipassana experience is manifest in the mind.

\section{One Emptiness}

Monteiro et al. made reference to the commonly held view that the notion of non-duality is primarily a Mahayana/ Vajrayana construct that is incompatible with the Theravada Buddhist framework of viewing existence through the dualistic lens of samsara (i.e. suffering) and nirvana (i.e. liberation). This relates closely to the popular belief that non-self (Pâli: anattā, Sanskrit: anātman) is primarily a Theravada construct that is distinct from the Mahayana/Vajrayana principle of emptiness (Pāli: suññatā, Sanskrit: śūnyatā). In essence within Mahayana/Vajrayana Buddhism, non-duality is another means of referring to and explicating the concept of emptiness. If a subject-object divide is not imposed on an individual's mode of perceiving, this means that a "subject self" that exists separately from an "object other" is no longer apprehended. Consequently, the experience of oneness, emptiness of self, and emptiness of other arises (Shonin. et al. 2013a). In our opinion, and in much the same vein as the previous assertion that the Buddha taught only one type of mindfulness, there exists (and the Buddha taught) only one type of emptiness, that is identical to-and encompassing of - the experiential meaning of both the terms non-self and non-duality. 
There are numerous lines of reasoning upon which this assertion is made. The first is that emptiness is explicitly and frequently referred to and taught throughout the Theravada Pāli Canon. For example, in the Majjhima Nikāya, amongst various other direct and indirect references to emptiness, there appears both the Shorter Discourse on Emptiness (Cülasuññata Sutta, MN 121) and the Greater Discourse on Emptiness (Mahāsuññata Sutta, MN 971). Emptiness (also translated as voidness) is likewise directly referred to in core Theravada texts such as the Dhammapada (that appears in the Khuddaka Nikāya of the Sutta Pitaka):

He whose cankers are destroyed ... whose object is the void, the unconditioned freedom - his path cannot be traced, like that of birds in the air (Dhammapada, 7, 93; Buddharakkhita 1986, p. 37).

Furthermore, the Mahavedalla Sutta (MN 43) appears to directly indicate that the Buddha deemed that emptiness/ voidness and non-self were equivalent constructs:

Here a bhikkhu, gone to the forest or to the root of a tree or to an empty hut, reflects thus: 'This is void of a self or of what belongs to a self'. This is called the deliverance of mind through voidness (Ñanamoli and Bodhi 2009, p. 394).

Even without the direct references to and discourses on emptiness in the Theravada Pāli Canon, the primary reason for asserting that there are limited grounds for assigning emptiness and non-duality as non-Theravadan constructs rests on a matter of both scientific and logical fact. All phenomena, without exception, originate and exist only in dependence upon innumerable causes and conditions. Consequently, as phenomena do not exist independently, by default, they lack an intrinsically existing self (Shonin et al. 2013a). In other words, emptiness is a truth that pervades the very strata of existence - it constitutes the underlying fabric of reality. Not only can this assertion be validated via deductive logical analysis (Shonin and Van Gordon 2013, 2014a) but there is also preliminary empirical evidence - mostly from the field of quantum mechanics - that attests to the truth and allpervading presence of emptiness (see Shonin and Van Gordon 2014a).

The Buddha is understood by all Buddhist traditions to have tapped into this liberating truth of emptiness and to have attempted - using various means - to guide others to do the same. However, irrespective of how it is referred to or interpreted, and as explicated in the Cülasuññata Sutta, the Buddha only ever taught that there exists one type of emptiness:

Ananda, whatever recluses and Brahmins in the past entered upon and abided in pure, supreme, unsurpassed voidness, all entered upon and abided in the same pure, supreme voidness [repeats for recluses and Brahmins of the present and those of future, who will all enter upon and abide in this same, supreme, unsurpassed voidness] (Ñanamoli and Bodhi 2009, p. 970).

Thus, much like water that, despite the number of competing assertions that could be made about its properties, will always behave in the same manner under identical conditions, emptiness remains a single truth irrespective of the number of claims made by researchers, scholars, and Buddhist teachers about the different types of emptiness that are supposed to exist (and that are advocated by different Buddhist traditions). Indeed, if Theravada Buddhist practitioners realize the nonself of themselves, then by logical default, they simultaneously realize the non-self or emptiness of everything else (because without a self there is no other). According to Shonin and Van Gordon (2014b), there is an underlying truth of emptiness, and a spiritual practitioner (Buddhist or otherwise) either begins to realize this truth or they remain experientially ignorant of it. In our opinion, it is when researchers, scholars, and Buddhist teachers remain experientially ignorant to the truth of emptiness, they are likely to speculate and develop flawed theories about what emptiness is, how it should be practised, and how it relates to other Buddhist teachings, such as mindfulness.

In the context of the present commentary, the purposes of highlighting the single, unchanging, and all-pervasive nature of emptiness is to further dispel the misconception that there are different types of mindfulness that vary according to how a particular Buddhist tradition constructs mindfulness, as well as how they construct and interpret other fundamental Buddhist teachings (e.g. emptiness). As referred to above, in order to meet the needs of spiritual practitioners from a broad range of backgrounds, the Buddha employed multiple methods of teaching. However, these various methods - some more direct than others - always pointed towards the existence of the same truth. In other words, there has only ever been one type of mindfulness, and there has (and will) only ever be one type of emptiness. Understanding the accurate and single nature of both mindfulness and emptiness is a prerequisite for effective spiritual growth, and the manner in which an individual practices and apprehends either one of these core Buddhist principles directly influences the extent to which they develop an accurate perception of the other (Shonin et al. 2014a).

\section{One Purpose}

Monteiro et al. also discussed the topical issue of whether it is appropriate for mindfulness to be utilized in military and business settings. In particular, the authors focused on the main objections to introducing mindfulness into such settings. The majority of these objections are based on the belief by some individuals that because mindfulness was originally 
taught as a means of fostering peace and spiritual awakening, it is ethically inappropriate to introduce mindfulness to the armed forces and/or commercial entities. However, as explicated below, there are also robust grounds for arguing that introducing mindfulness to military and business personnel is in keeping with traditional Buddhist values and ideals.

A core principle of Buddhist practice is generosity and this includes generosity in the sharing of the Buddha's teachings (Gampopa 1998). Indeed, not only does restricting the integration of mindfulness into military and business settings run contrary to the popular view - mostly held by advocates of secular mindfulness-based approaches - that mindfulness practice requires a "non-judgemental" attitude but, according to Shonin and Van Gordon (2014c, p. 1), it also denies individuals the right and opportunity to encounter and practice the spiritual teachings:

The Buddhist teachings (known as the Dharma) - which include teachings on mindfulness - are universal in their application. It does not matter if a person is rich or poor, good or bad, famous or obscure, young or old, male or female, or if they purport not to have an interest in matters of a spiritual nature - the Dharma is available for everybody to benefit from. Indeed, it is not for anybody - not even the Buddha- to decide which people should be denied the spiritual teachings and which people should receive them. Each person must make that choice on an individual basis and, really and truly, the only way they can make an informed decision about whether a particular form of spiritual practice is right for them, is if they have the opportunity to try it first. Therefore, introducing military personnel to the mindfulness teachings brings people working in military settings into contact with the Dharma and gives them the opportunity to make an informed decision as to whether mindfulness is a practice they would like to integrate into their lives.

According to Buddhist thought, the Buddha's teachings can be likened to an all-purpose medicine (Tsong-Kha-pa 2004). The key principles of this view are that (i) due to their purity and potency, the inevitable outcome for an individual that receives the Buddha's teachings - including those relating to mindfulness - is an increase in wisdom, compassion, and awareness and (ii) in the event that such qualities do not manifest, it is because the teachings have been incorrectly taught and/or incorrectly practised (Shonin and Van Gordon 2014c). In essence, what is being alluded to is what we have previously referred to as an inbuilt natural protection mechanism of the Buddhist teachings:

If a person comes into contact with the Dharma who is not ready to receive the teachings or who intends to use them for selfish or negative purposes, their wrong intention will prevent the teachings from taking root within their being. In fact, all that they will receive will be a theoretical and superficial account of the teachings - and even this won't be properly understood (Shonin and Van Gordon 2014c, p. 1)

In view of heightened inter- and intra-territorial tensions in the world, it seems that the majority of governments believe that an armed force is essential for acting as a deterrent to invasion, terrorist attack, and/or civil unrest. In such an uncertain and arguably hostile economic and political global climate, rather than refuse to introduce responsible military leaders to the principles of mindful awareness, we argue that a more rational solution is to deploy military personnel and leaders that are fully aware of the consequences of their thoughts, words, and actions and who carry out their role with wisdom and compassion.

The Buddha's fundamental intent when deciding to expound the Buddha-dharma was to alleviate suffering, and he was unconditional in the manner in which he extended this invitation and opportunity to others (i.e. the Buddha only refused to teach an individual in circumstances where they had already abused his trust and kindness, and thus provided reasonable grounds for determining that it would be unprofitable to continue trying to teach them at that particular stage of their life) (Van Gordon et al. 2014a). When and where mindfulness is correctly taught to individuals, empirical research demonstrates that not only are participants likely to experience improvements in psychological wellbeing and role competency but - to admittedly differing degrees - they are also likely to engender a more compassionate outlook and to grow in spiritual insight (e.g. Shonin and Van Gordon 2014d; Van Gordon. et al. 2014). However, when and where mindfulness is incorrectly taught —including where it is taught outside of a framework of ethical awareness - then the resultant construct can no longer be said to bear any resemblance to a traditional construction of mindfulness. In such circumstances, the entire issue of whether it is ethically and morally correct to introduce mindfulness into military and/or business settings becomes redundant (because what is being introduced and practised is something other than mindfulness).

\section{One Teacher}

Monteiro et al. also made reference to the various concerns that have been raised in the academic and popular literature concerning the competency of instructors of mindfulnessbased interventions. Such concerns arise because in the traditional Buddhist setting, meditation teachers would typically undergo many years (and in many cases decades) of focused daily training before being considered adequately experienced 
to begin teaching and guiding others in meditative and spiritual practice (Shonin et al. 2014b). In our view, these concerns are entirely justified because there are reports of individuals teaching mindfulness following completion of just a single eight-week programme (Mental Health Foundation 2010). However, there is a danger of vilifying secular mindfulnessbased approaches and pitching them (and their respective teachers) as superficial versus their "authentic" Buddhist counterparts.

Compared to teachers of secular mindfulness-based approaches, it is arguably much easier for teachers of mainstream Buddhism to trace and make a claim to some kind of authentic Buddhist lineage. However, the act of "belonging" to a lineage provides little if any assurance as to the spiritual realization of a particular Buddhist teacher and/or their suitability to teach meditation. As we have previously argued, the single most important factor when attempting to gauge the suitability and competency of a meditation teacher is the extent to which they have amassed authentic spiritual and meditative realization (Shonin and Van Gordon 2014b). If a secular mindfulness teacher has given rise to authentic spiritual insight and instructs others from an experientially informed perspective, they are fully capable (both practically and morally) to teach mindfulness. Conversely, if a teacherincluding a teacher of mainstream Buddhism - has not given rise to such insight, then irrespective of the number of lineages, titles, or endorsements they hold, they should not be considered as authentic.

According to certain systems of Buddhist thought, the current epoch corresponds to a period of spiritual degeneration (Sanskrit: pashchimadharma, Japanese: mappō) and is characterized by the widespread demise of the spiritual teachings (Marra 1988). Consequently, and almost without exception, the core texts and commentaries of the Theravada, Mahayana, and Vajrayana Buddhist approaches - which in some cases are thousands of years old - repeatedly refer to the risk of spiritual practitioners and teachers becoming knowingly or unknowingly corrupt in their embodiment of the Buddhadharma, and how in future periods (i.e. present times) instances of such corruption are likely to significantly increase.

Even as long as 1200 years ago when the Buddhist (and spiritual) teachings were at a much earlier phase of decline (known as the Age of Semblance Dharma; Sanskrit: pratirupadharma, Japanese: $z \bar{o} b \bar{o}$ ), the Chinese Zen teacher Huang Po repeatedly made reference to the prevalence of corruption and deluded views held by Buddhist teachers and practitioners. He estimated that only five out of every ten thousand practitioners that were focused on attaining enlightenment would be able to substantiate a claim to authentic spiritual realization (Huang Po 1982). Twelve centuries later, when the Buddhist teachings are believed to be at a more advanced state of degeneration (Marra 1988), it is logical to assume that Huang Po's estimate would need to be significantly revised (e.g. only five out of every hundred thousand, million, or even ten million diligent Buddhist practitioners attaining at least a moderate degree of lasting and authentic spiritual insight). However, given that Huang Po's estimate referred only to those individuals that had set their intentions firmly on attaining enlightenment (e.g. monks, nuns, diligent lay practitioners), and given, in all likelihood, that the majority of individuals and teachers practising meditation at present time would not meet Huang Po's criteria of being a focused/diligent practitioner, we would envisage that the number of Buddhist teachers with authentic spiritual realization is significantly less than most Buddhist and nonBuddhist spiritual practitioners may have been led to believe.

Therefore, although the underlying truths of existence that the Buddha attempted to introduce to others are incorruptible (Norbu and Clemente 1999), claims by some researchers, scholars, and Buddhist teachers that Buddhism "is in the right" and secular mindfulness-based approaches are "in the wrong" are in certain instances likely to be examples of such individuals demonstrating the same pious and superficiality that they aver is embodied by the recent secular mindfulness movement. The crux of the matter is that if a teacher of either Buddhism or a secular mindfulness-based approach is sincere in their meditation practice and has touched or tapped into emptiness (and thus made inroads into undermining their ego), then recipients of their teachings- whether in Buddhist or secular (e.g. clinical) contexts - are likely to derive lasting benefit from their participation (Shonin and Van Gordon 2014b). A small body of empirical qualitative research supports this assertion and suggests that sincerity and experience on the part of the mindfulness teacher are key determinants of successful intervention outcomes (e.g. Shonin. et al. 2013b; Shonin and Van Gordon 2014d).

\section{One Mindfulness Community}

Even when Shakyamuni Buddha was still alive, certain recipients of his wisdom felt the need to systematize, categorize, and conceptualize the various teachings that he imparted. Although the Buddha encouraged questioning and investigation of his teachings, he was clear right from the outset with his followers that the various truths he was attempting to convey could only be realized as a result of sustained effort and practice, and that over-conceptualization of these truths was an unprofitable endeavour (e.g. Dhammacakkappavattana Sutta, SN 56; Bodhi 2000). However, some 2500 years after the Buddha's death, it is clear that for the most part, his message of simplicity and the importance of arriving at an experiential (rather than theoretical) understanding of his teachings have not been heeded. Within contemporary society, there exist numerous different traditions of Buddhism, each with their own interpretation of 
the Buddha's teachings, and each with their own view regarding the extent to which other Buddhist traditions deviate from the Buddha's original and intended meaning. Arguably, the most obvious example of this division in the Buddhist teachings occurs when comparing the Theravada perspective with that of either the Mahayana or Vajrayana Buddhist vehicles. Obviously, the manner in which Buddhism evolves will vary according to the receptivity, culture, and existing beliefs of the population in which it finds itself (Dunne 2011). Nevertheless, as repeatedly emphasized and demonstrated throughout this commentary, the Buddha was entirely consistent in his teachings, and any alleged differences in the meaning of his instructions ultimately arise as a result of conceptual elaborations that, in general, are often of limited scriptural or logical soundness.

Reading and understanding the works of any genuinely accomplished Buddhist practitioner should lead an individual to the realization that divisions in the Buddhist teachings are ultimately "man-made". For example, we would argue that any experienced Buddhist scholar would have difficulty in denying the strong Vajrayana undercurrent that runs throughout the works of the Theravada Buddhist teacher Rājvudhācāriya (see, for example, Rājvudhācāriya 2010). Likewise, in the Theravada Pāli Canon, there are numerous examples of individuals (such as Añña Kondañña [Bodhi 2000] and Upāli [Ñanamoli and Bodhi 2009]) undergoing a sudden awakening (normally associated with Mahayana [particularly Zen] and Vajrayana Buddhism) upon hearing even the most fundamental of Buddhist teachings (e.g. the Four Noble Truths).

Although we have argued in this paper that some of the terms utilized by researchers, scholars, and Buddhist teachers to refer to mindfulness (and other Buddhist principles) have been employed with limited scriptural or logical soundness, it needs to be remembered that in the context these definitions were offered, they may not necessarily represent erroneous explications. For example, if Trungpa's (2004) aforementioned depiction of mindfulness as (rather than an integral part of) shamatha meditation brought recipients of his teachings to an accurate and/or experiential understanding of mindfulness (and/or shamatha), then how can it be argued that contextualizing mindfulness in such a manner was in anyway inappropriate? In a similar vein, although (to a much greater extent) there are differences between how mindfulness is taught and practised in both Buddhist and secular mindfulness-based approaches, if secular approaches offer an efficacious means of alleviating suffering - and the evidence suggests that they do (Hofmann. et al. 2010) - then the value of critically highlighting the means by which they deviate from a traditional or contemporary Buddhist contextualization becomes somewhat questionable.

We would argue that concerns regarding the extent to which contemporary mindfulness-based approaches are compatible with the traditional Buddhist model have been comprehensively raised and are duly noted by both the scientific and Buddhist community. Consequently, in the spirit of both Buddhist and contemporary secular mindfulness teaching ideals, perhaps an appropriate point has been reached for the scientific and Buddhist communities to work more closely together and as a single mindfulness community, seek to develop and empirically validate interventions and/or teaching modes that are effective according to both clinical and spiritual criteria.

\section{References}

Bishop, Lau, M., Shapiro, S., Carlson, L., Anderson, N. D., Carmody, J., Segal, Z. V., \& Devins, G. (2004). Mindfulness: a proposed operational definition. Clinical Psychology: Science and Practice, 11, 230-241.

Bodhi, B. (2000). The connected discourses of the Buddha: a new translation of the Samyutta Nikaya. Massachusetts: Wisdom.

Bowen, S., Witkiewitz, K., Dillworth, T. M., Chawla, N., Simpson, T. L., Ostafin, B. D., \& Marlatt, G. A. (2006). Mindfulness meditation and substance use in an incarcerated population. Psychology of Addictive Behaviours, 20, 243-347.

Brown, K. W., Ryan, R. M., \& Creswell, J. D. (2007). Mindfulness: theoretical foundations and evidence for its salutary effects. Psychological Inquiry, 18, 211-237.

Buddharakkhita. (1986). Dhammapada: A practical guide to right living. Bangalore: Maha Bodhi Society.

Chah, A. (2011). The collected teachings of Ajahn Chah. Northumberland: Aruna.

Chiesa, A. (2010). Vipassana meditation: systematic review of current evidence. Journal of Alternative and Complementary Medicine, 16, $37-46$.

Dunne, J. (2011). Toward an understanding of non-dual mindfulness. Contemporary Buddhism, 12, 71-88.

Foundation, M. H. (2010). Mindfulness report. London: Author.

Gampopa. (1998). The Jewel Ornament of Liberation: The wish-fulfilling gem of the noble teachings. (A. K. Trinlay Chodron, Ed., \& K. Konchong Gyaltsen, Trans.) New York: Snow Lion Publications.

Gelek, R. (2009). The song of four mindfulnesses. Ann Arbor: Jewel Heart Transcripts.

Hofmann, S. G., Sawyer, A. T., Witt, A. A., \& Oh, D. (2010). The effect of mindfulness-based therapy on anxiety and depression: a metaanalytic review. Journal of Consulting and Clinical Psychology, 78, 169-183.

Horowitz, S. (2010). Health benefits of meditation: what the newest research shows. Alternative and Complementary Therapies, 16, 223-228.

Huang Po. (1982). The Zen Teaching of Huang Po: On the Transmission of the Mind. (Blofeld, J., Trans.) New York: Grove Press.

Kabat-Zinn, J. (1982). An outpatient program in behavioral medicine for chronic pain patients based on the practice of mindfulness meditation: theoretical considerations and preliminary results. General Hospital Psychiatry, 4, 33-47.

Kabat-Zinn, J. (1990). Full catastrophe living: using the wisdom of your body and mind to face stress, pain and illness. New York: Delacourt.

Kabat-Zinn, J. (1994). Wherever you go, there you are: mindfulness meditation in everyday life. New York: Hyperion.

Kabat-Zinn, J., Wheeler, E., Light, T., Skillings, A., Scharf, M. J., Cropley, T. G., \& Bernhard, J. D. (1998). Influence of a mindfulness meditation-based stress reduction intervention on rates of skin clearing in patients with moderate to severe psoriasis undergoing 
phototherapy (UVB) and photochemotherapy (PUVA). Psychosomatic Medicine, 60, 625-632.

Kang, C., \& Whittingham, K. (2010). Mindfulness: a dialogue between Buddhism and clinical psychology. Mindfulness, 1, 161-173.

Krishnamurti, J. (2009). Freedom from the known. San Francisco: Harper Collins.

Lama, D., \& Berzin, A. (1997). The Gelug/Kagyu tradition of Mahamudra. New York: Snow Lion.

Lutz, A., Slagter, H. A., Dunne, J. D., \& Davidson, R. J. (2008). Attention regulation and monitoring in meditation. Trends in Cognitive Sciences, 12, 163-169.

Manocha, R. (2000). Why meditation? Australian Family Physician, 29, $1135-1138$.

Marra, M. (1988). The development of mappō thought in Japan. Japanese Journal of Religious Studies, 15, 26-27.

McGarvey, M. K. (2010). Mindfulness practices and emotional development in adult life: a developmental framework for research and teaching. Harvard: Harvard Graduate School of Education.

Monteiro, L. M., Musten, R. F., \& Compson, J. (2015). Traditional and contemporary mindfulness: finding the middle path in the tangle of concerns. Mindfulness, 6, 1-13.

Nanamoli. (1979). The Path of Purification: Visuddhi Magga. Kandy (Sri Lanka): Buddhist Publication Society.

Ñanamoli, B., \& Bodhi, B. (2009). Majjhima Nikaya: the middle length discourses of the Buddha (4th ed.). Massachusetts: Wisdom.

Norbu, C., \& Clemente, A. (1999). The supreme source: the fundamental tantra of the Dzogchen Semde. New York: Snow Lion.

Nyanaponika, T. (1962). The heart of Buddhist meditation. New York: Samuel Weiser.

Rājvudhācāriya. (2010). Citta is Buddha. Bangkok: Chuanpin.

Rosch, E. (2007). More than mindfulness: when you have a tiger by the tail, let it eat you. Psychological Inquiry, 18, 258-264.

S. Mipham. 2002. Shamatha meditation: training the mind Available at: http://www.lionsroar.com/training-the-mind/ (Accessed 15 November 2014)

Shonin, E., \& Van Gordon, W. (2013). Searching for the present moment. Mindfulness, 5, 105-107.

Shonin, E., \& Van Gordon, W. (2014a). Dream or reality? Philosophy Now, 104, 54

Shonin, E., \& Van Gordon, W. (2014b). The lineage of mindfulness. Mindfulness. doi:10.1007/s12671-014-0327-x.
Shonin, E., \& Van Gordon, W. (2014c). Should mindfulness be taught to the military? Available at: http://edoshonin.com/2014/08/08/shouldmindfulness-be-taught-to-the-military/ (Accessed 8 November, 2014).

Shonin, E., \& Van Gordon, W. (2014d). Managers' experiences of meditation awareness training. Mindfulness. doi:10.1007/s12671-0140334-y.

Shonin, E., Van Gordon, W., \& Griffiths, M. D. (2013a). Buddhist philosophy for the treatment of problem gambling. Journal of Behavioral Addictions, 2, 63-71.

Shonin, E., Van Gordon, W., \& Griffiths, M. D. (2013b). Meditation awareness training (MAT) for improved psychological wellbeing: a qualitative examination of participant experiences. Journal of Religion and Health, 53, 849-863.

Shonin, E., Van Gordon, W., \& Griffiths, M. D. (2014a). The emerging role of Buddhism in clinical psychology: toward effective integration. Psychology of Religion and Spirituality, 6, 123137.

Shonin, E., Van Gordon, W., \& Griffiths, M. D. (2014b). Are there risks associated with using mindfulness for the treatment of psychopathology? Clinical Practice, 11, 389-392.

Shonin, E., Van Gordon, W., \& Griffiths, M. D. (2014c). Mindfulness and wellbeing: towards a unified operational approach. In I. Ivtzan \& T. Lomas (Eds.), Mindfulness in positive psychology: the science of meditation and wellbeing. Oxford: Routledge. (in press)

Sills, M., \& Lown, J. (2008). The field of subliminal mind and the nature of being. European Journal of Psychotherapy and Counselling, 10, $71-80$.

Trungpa, C. (2004). The collected works of Chogyam Trungpa (Vol. 8). Boston: Shambhala.

Tsong-Kha-pa. (2004). The great treatise on the stages of the path to enlightenment. New York: Snow Lion.

Van Gordon, W., Shonin, E., Griffiths, M. D., \& Singh, N. N. (2014a). Mindfulness and the Four Noble Truths. In E. Shonin, W. Van Gordon, \& N. N. Singh (Eds.), Buddhist foundations of mindfulness. New York: Springer. (in press)

Van Gordon, W., Shonin, E., Zangeneh, M., \& Griffiths, M. D. (2014b). Work-related mental health and job performance: can mindfulness help? International Journal of Mental Health and Addiction, 12, $129-137$. 